\title{
PROBLEMY NIEFORMALNYCH OPIEKUNÓW SENIORÓW W RODZINIE - KWESTIA WAŻNA CZY MAŁO WAŻNA? ROZWAŻANIA NIEARBITRALNE
}

\section{PROBLEMS OF INFORMAL SENIORS' CAREGIVERS IN THE FAMILY - AN IMPORTANT OR NEGLIGIBLE ISSUE? NON-ARBITRARY REFLECTIONS}

\author{
Wanda MUSIALIK \\ Politechnika Opolska \\ Wydział Ekonomii i Zarządzania, Katedra Międzynarodowych Stosunków Społecznych \\ ul. Luboszycka 7, 45-036 Opole \\ w.musialik@po.opole.pl
}

\begin{abstract}
Zarys treści: W artykule przedstawiono wybrane problemy nieformalnych opiekunów osób starszych w rodzinie z terenów wiejskich ${ }^{1}$. Oszacowano ekonomiczny wymiar ich nieodpłatnej pracy. Przedstawiono strukturę opiekunów seniorów w rodzinach pod względem wieku, poziomu edukacji, stanu cywilnego, a także sektora zatrudnienia pracujących i rodzaju zajęć niezatrudnionych osób. Dane dotyczące wsi zestawiano z danymi charakteryzującymi sytuację w miastach. Na podstawie przeglądu literatury z zakresu gerontologii, pielęgniarstwa i zdrowia publicznego określono zagrożenia zdrowotne i społeczne związane z podjęciem roli opiekuna osób „u schyłku życia”. Stwierdzono, że wiedza teoretyczna z zakresu CSS (Caregiver Stress Syndrome) - do polskojęzycznych publikacji specjalistycznych trafiająca w ostatnich pięciu latach - nie znajduje odzwierciedlenia w praktycznych działaniach na rzecz wsparcia potrzeb nieformalnych opiekunów seniorów w rodzinach. Uwaga publiczna skupia się na seniorach, pozostawiając osoby, które sprawują nad nimi pieczę w swoistym kręgu wykluczenia.
\end{abstract}

Słowa kluczowe: nieformalni opiekunowie osób starych z terenów wiejskich, nieodpłatna praca kobiet, syndrom opiekuna, Caregiver Stress Syndrome, wykluczenie społeczne.

\section{Wstęp}

Udział polskich naukowców w międzynarodowym projekcie badawczym EURO-FAMCARE w latach 2003-2005 zwrócił uwagę specjalistów z zakresu medycyny na problemy nieformalnych opiekunów rodzinnych. Chociaż zagadnienie to pojawiło się w literaturze znacznie wcześniej, to skierowanie uwagi na rolę, jaką pełnią opiekunowie osób w pode-

\footnotetext{
${ }^{1}$ W Polsce trwa dyskusja nad przyjęciem jednoznacznego pojęcia dla członków rodziny troszczących się o krewnego niepełnosprawnego z uwagi na podeszły jej wiek (Janowicz 2014, s. 161).
} 
szłym wieku w Polsce należy do kwestii z trudem przebijających się do opinii społecznej w pierwszych dziesięcioleciach XXI w. W opracowaniu starano się odpowiedzieć na pytanie, czym tłumaczyć można wcześniejszy brak zainteresowania problemami opiekunów rodzinnych osób starych, a także jakie trudności przysparzało podjęcie takiej formy aktywności. Świadczenie tej opieki w rodzinach, uznane za polską normę społeczną (Racław 2012, s. 76), zachodzi bez przepływów finansowych, rzeczywiście jednak generuje koszty ponoszone przez osoby ją sprawujące, jak i ich rodziny, a także społeczności, w których funkcjonują.

W dwóch okresach życia człowieka pomoc drugiej osoby w codziennym funkcjonowaniu jest nieodzowna. Pierwszy z nich przypada na lata niemowlęce i dzieciństwa, kiedy człowiek dopiero pozyskuje umiejętności potrzebne do funkcjonowania w życiu. Drugi okres to lata senioralne - czas postępującej utraty nabytych umiejętności fizycznych i społecznych. W zainteresowaniu publicznym zauważyć można brak symetrii pomiędzy tymi dwoma okresami zapotrzebowania na opiekę pozainstytucjonalną. Nakłady finansowe związane z rozstrzyganiem problemów okresu pierwszego są o wiele większe od tych związanych ze schyłkowym okresem zależności człowieka od wsparcia innych osób. Stwierdzenie to znajduje odzwierciedlenie zarówno w badaniach naukowych poświęconych owym problemom, jak i praktyce życia codziennego. Zainteresowanie i środki społeczne skupiają się przede wszystkim na kwestiach związanych z osiągnięciem sprawności społecznej podopiecznego. I dzieje się tak niezależnie od miejsca zamieszkania podopiecznego, czy jest nim miasto, czy też wieś.

\section{Polskie ustawodawstwo socjalne na rzecz nieformalnych opiekunów rodzinnych}

Zagadnienia pierwszego okresu życia zwracają uwagę specjalistów z zakresu pedagogiki, edukacji, psychologii, polityki społecznej, polityki rodzinnej czy prawa pracy. Odpowiedzią na dostrzeżone problemy opiekunów osób nieletnich stały się zasiłki i urlopy macierzyńskie (Godlewska 1984; Graniewska i in. 1991), urlopy wychowawcze, a także ojcowskie (Kołaczek 1990). Uprawnienia do korzystania z owych udogodnień w przypadku urlopu wychowawczego wprowadzono już w 1947 r., zmian dokonano w 1966 r. (Dzienio i Lach 1983, s. 262) oraz kolejnych w dziesięcioleciach lat 70. i 80. (Godlewska 1984). Następne nowelizacje wprowadzono po upływie ćwierć wieku, tj. w 2009 r. (Mazur 2009). W 2015 r. zapowiedziano rozszerzenie grupy osób korzystających z pomocy finansowej w związku z opieką nad dziećmi².

Do tej praktyki należały też programy zmierzające do przywrócenia aktywności zawodowej kobiet, które korzystały ze wspomnianych form opieki nad dzieckiem (Sadowska-Snarska i Tchon 2008). O stałych wysiłkach na rzecz osób wychowujących dzieci świadczy planowane w Nysie na Opolszczyźnie wprowadzenie od 2016 r. bonu opiekuńczo-wychowawczego dla pracujących rodziców dzieci w wieku od 1 do 6 lat. W uzasadnieniu podjęcia tego programu odwołano się do motywów ekonomicznych związanych z zatrzymaniem emigracji tej grupy osób (Nysa zapowiada... 2015).

2 Od 2016 r. wszystkie rodziny przez rok po urodzeniu dziecka będą otrzymywać co najmniej 1 tys. złotych miesięcznie. Jest to płatny urlop rodzicielski - macierzyński dla bezrobotnych, studentów, ubezpieczonych w KRUS. www.kartaduzejrodziny.pl/w-polityce/367-platny-urlop-macierzynski-dla-bezrobotnych-studentowubezpieczonych-w-krus-1-tys-zl-na-dziecko.html_11.04.2015 
Podobnego systemowego wsparcia w Polsce dotąd nie wypracowano dla osób zajmujących się nieformalną opieką nad seniorami w rodzinach. Od 1964 r. istnieje możliwość korzystania z zasiłku opiekuńczego. Przepisy prawne normujące dostęp do niego zmieniane były w 2012 i 2015 r. (Zasiłek pielęgnacyjny... 2015). Od stycznia 2015 r. dołączono do nich możliwość uzyskania specjalnego zasiłku opiekuńczego przez osoby zajmujące się osobą starszą o określonym stopniu niepełnosprawności³ (Brzostek 2014).

\section{Historyczne przesłanki dysproporcji}

Jednym z powodów wspomnianych różnic w systemie wsparcia w rodzinie osób troszczących się o dzieci i seniorów może być stosunkowo niewielka świadomość bezpośredniego ekonomicznego wpływu na funkcjonowanie nieformalnych opiekunów rodzinnych osób starszych. Wiąże się to prawdopodobnie z przekonaniem, że system emerytalny - znany od drugiej połowy XIX w., którym w latach 70. XX w. objęto także rolników - rozwiązuje negatywne przejawy funkcjonowania na wsi tzw. „wymowy” lub „wycugu”, tj. notarialnego zobowiązania potomka do opieki w zamian za dziedziczenie gospodarstwa rolnego ${ }^{4}$. Stąd też problemy towarzyszące opiekunom osób dożywających końca egzystencji z terenów wsi występowały sporadycznie i marginalnie na łamach publikacji. Stawały się wątkiem pamiętników (Skorupka 1974 , s. 23, 87), a w pracach naukowych zaś domeną antropologów i etnografów (Świętek 1896 [?]; Bednarska 1976, s. 444; Simonides 1989, s. 150) lub osób zajmujących się historią wątków chłopskich w literaturze (Eile 1973, s. 57; Łoch i in. 2006, s. 293) bądź dziejami ludności wiejskiej (Inglot 1980, s. 473; Grzelak 1981, s. 313; Michalkiewicz 1985, s. 689). Bardzo rzadko temat podejmowano w przypadku innych grup społecznych, do wyjątków należy praca o starości w rodach pirenejskich (Fauve-Chamoux $1991^{15}$.

Marginalne zainteresowanie sprawami osób zajmujących się seniorami podyktowane było też prawdopodobnie okolicznością pozostawania tego zadania w obrębie funkcji pełnionych przez wielopokoleniowa rodzinę (Błędowski i in. 2012, s. 115). Tam zaś rolę tę powierzano kobietom, którym tradycja i płynące stąd stereotypy przypisywały funkcje opiekuńcze (Kawczyńska-Butrym 2008, s. 38-39). Przez dziesięciolecia nie uznawano wykonywanych przez nie zadań domowych za zajęcia równorzędne pracy zarobkowej. O opiece nad osobami „u schyłku życia” jako części nieodpłatnej pracy domowej kobiet zaczęto w Polsce mówić w 2004 r. (Titkow i in. 2004), ale dotąd nie wypracowano rozwiązania, które mogłoby przynieść satysfakcję materialną osobom, które wnosiły ową nieodpłatną pracę. Brak jej wymiaru dochodowego przekłada się z jednej strony na brak podatków, z drugiej na wysokość składek emerytalnych, które ewidentnie obniżą przyszłe emerytury osób sprawujących nieformalną opiekę rodzinną.

3 Prawo do specjalnego zasiłku opiekuńczego przysługuje osobom, na których ciąży obowiązek alimentacyjny na podstawie przepisów Kodeksu rodzinnego i opiekuńczego. Od 1 stycznia 2015 r. o zasiłek mogły starać nie tylko osoby, które w celu sprawowania opieki zrezygnowały z pracy, a także te, które z powodu sprawowania stałej opieki nad osobą niepełnosprawną w ogóle nie podjęły zatrudnienia lub innej pracy zarobkowej. Wysokość tego zasiłku wynosi 520 zł.

4 Skalę problemu odzwierciedla podjęcie wątku Macieja Boryny, bohatera w powieści Władysława Rejmonta Chłopi, powstałej w latach 1901-1908 (Łoch i in. 2006, s. 293).

5 Szerzej o tym: W. Musialik, Opiekunowie osób „czwartego wieku” w piśmiennictwie od 2. poł XIX do XXI w. - referat przedstawiony 22.05.2015 r. podczas konferencji „Dzieciństwo i starość w historiografii” przygotowanej przez Zakład Historii Polski Średniowiecznej i Dziejów Gospodarczych Instytutu Historii Uniwersytetu Marii Curie-Skłodowskiej w Lublinie. 
Ów niedostatek zainteresowania można by tłumaczyć niewielką grupą osób dotkniętych tym problemem albo nieistotnym wymiarem godzin przeznaczanych na ten rodzaj zajęć. Otóż w badaniach europejskiego grantu EURO-FAMCARE, trwającego w latach 2003-2004, wykazano, że zasób opiekunów nieformalnych w Polsce wynosił około 2 mln osób (Racław 2012, s. 76; Janowicz 2014, s. 164).

\section{Wymiar ekonomiczny bezpłatnej pracy nieformalnych opiekunów rodzinnych}

Centrum Badań Opinii Społecznej w sondażach przeprowadzonych 2012 r. ustaliło, że w grupie ich respondentów (1017 osób) co piąty opiekun poświęcał na ten cel w tygodniu dziesięć godzin (22\%), co dziesiąty - powyżej 40 godzin (11\%). Wraz ze wzrostem wymiaru godzin opieki rósł stopień braku satysfakcji z udzielania takiej pomocy. Najniższy był wówczas, kiedy poza pomocą w zakupach, sprzątaniu, praniu, przygotowywaniu posiłków, pomoc seniorowi związana była z utrzymaniem jego higieny osobistej i ubieraniem (Omyła-Rudzka 2012, s. 1, 6), czyli brakiem pełnej samodzielności podopiecznego. Wówczas też opiekunowie deklarowali, że obowiązki z tym związane są dla nich uciążliwe (Omyła-Rudzka 2012, s. 8). W innym sondażu 87\% respondentów spośród nieformalnych opiekunów rodzinnych deklarowało chęć sprawowania opieki nad seniorem (Racław 2012, s. 76; Janowicz 2014, s. 164). Pozostała część z nich nie złożyła podobnej deklaracji. Różne mogły być tego powody, m.in. utracone zarobki.

Można zastosować wiele mierników wartości tej nieodpłatnie wykonanej pracy (Jurek 2007, s. 112; Racław 2012, s. 78). Jedna z metod przewiduje zastosowanie mnożnika godziny płacy minimalnej przez liczbę godzin wykonanej pracy. W przypadku osób poświęcających 40 godzin tygodniowo (40 godzin x 10,5 zł x 4 tygodnie) należność za ową pracę równałaby się minimalnej płacy. W 2012 r. stawki godzinowe profesjonalnych prywatnych opiekunów były zróżnicowane: przy opiece dziennej osoby chodzącej 13-15 zł za godzinę w tygodniu, 17-25 zł za godzinę w weekendy i święta. Wynagrodzenie za pracę wynosiłoby 2400 zł brutto przy 40 godzinach pracy w tygodniu6 (O cenach usług opiekunek... 2015).

W badaniach czynników ryzyka opieki nad chorymi z otępieniem i zaburzeniami poznawczymi oszacowano, że taka pomoc trwa średnio około 6 lat (Karczewska i in. 2012, s. 62, 64). Przyjmując ów okres za przeciętny czas trwania nieformalnej pracy opiekuna seniora w rodzinie tak w obszarach wiejskich, jak i miejskich, to podejmujący ten obowiązek (niejako) akceptuje utratę płacy za pracę oraz składek emerytalnych z tytułu tego wynagrodzenia. W przypadku osób przeznaczających 40 godzin tygodniowo na tę formę opieki utracony przychód przez 6 lat wynosił 120960 zł, a 23600 zł wynosiłby nieuzyskany przyrost kapitału emerytalnego ${ }^{7}$. Brak takich sum wpływa na ograniczenie zaspakajania materialnych potrzeb opiekuna tak w czasie pełnienia przez niego opieki, jak też kiedy on sam osiągnie wiek ustawowej bierności zawodowej. Sytuacja nieotrzymywania wynagrodzenia wpływa na materialne upośledzenie opiekuna seniora niezależnie od miejsca zamieszkania, zrównuje pod tym względem mieszkającego w mieście z mieszkańcem wsi. Brak zapłaty za włożoną pracę w opiekę nad niesamodzielną osobą starszą obniża również

\footnotetext{
${ }^{6}$ Według danych z lipca 2012 r.

7 Podane kwoty są orientacyjne.
} 
poziom zaspokajania potrzeb członków rodzin owych nieformalnych opiekunów ${ }^{8}$. Z uwagi jednak na to, że nie obciąża kosztowo budżetu publicznego, traktowana jest jako pomoc „bezpłatna” (Jurek 2007, s. 112).

W ocenie tej nie uwzględniono korzyści, jakie przyniosłaby obecność tych środków finansowych na rynku wewnętrznym. Ekonomistom pozostawiam kwestię oszacowania, czy kwota miesięczna, jaką dysponowałoby 220 tys. osób zajmujących się nieformalnie seniorami w rodzinach przez 40 godzin i więcej tygodniowo, tj. ok. 272184000 zł (wg stawek płacy minimalnej z 2014 r., tj. - 1237,20 zł płacy netto x 220 tys. osób) oddziałuje w ciągu roku na dynamikę handlu wewnętrznego w rejonach wiejskich i obszarach miejskich, a kwota 33264000 zł składki zdrowotnej wpłynęłaby na stan państwowej służby zdrowia.

\section{Charakterystyka ogólna nieformalnych opiekunów w rodzinach wiejskich na tle sytuacji w miastach}

Możliwość korzystania z odpłatnej pomocy zewnętrznej jest bez wątpienia większa w miastach, zwłaszcza dużych. Na wsi podobnej pomocy trudno oczekiwać z uwagi na brak rynku tych usług, a także zasobności finansowej potencjalnie potrzebujących owej pomocy. Ale potrzeby tam są większe, gdyż na wsi żyje proporcjonalnie większa liczba osób niepełnosprawnych. W 2002 r. w przeliczeniu na 1000 mieszkańców na wsi było takich osób 153, w mieście zaś 143 (Kawczyńska-Butrym 2008, s. 42).

Wydłużenie okresu trwania życia przekłada się na możliwość wystąpienia u osób starszych chorób związanych z otępieniem i zaburzeniami poznawczymi. Prawdopodobieństwo tej niesprawności u osób 65-letnich oszacowane zostało na 1\%, zaś u 85-letnich wzrasta do 40\% (Karczewska i in. 2012). Przy średniej długości życia na wsi 71,1 lat mężczyzn" a kobiet 81 lat (Rocznik Statystyczny... 2013, s. 213), to właśnie one dłużej mogą pomagać przy opiece nad wnukami czy prawnukami, ale też dłużej potrzebować będą wsparcia osób trzecich.

W pierwszym dziesięcioleciu XXI W. na wsi nieformalnymi opiekunami rodzinnymi w większej części niż w mieście były osoby będące pomiędzy 18 a 49 rokiem życia. Do 33 roku życia było ich tam więcej o 5,6 punktu procentowego w stosunku do nieformalnych opiekunów w tej grupie wiekowej mieszkających w miastach. W przedziale wieku 34-49 lat na wsi było owych opiekunów o 14,6 p.p. więcej niż w miastach ${ }^{10}$ i stanowili oni blisko połowę, tj. 44,7\% nieformalnych opiekunów seniorów mieszkających na wsi. W grupie wiekowej 50-64 lata opiekunów mieszkających na wsi było o 8,1 p.p. mniej niż w miastach. Najmniejszy udział wśród opiekunów na wsi stanowiły osoby w wieku 65 lat i więcej. Jednocześnie odsetek ten był dwukrotnie mniejszy od udziału takich osób mieszkających w miastach (Czekanowski 2006, s. 87) (tab. 1).

Na wsi w stosunku do miast wśród opiekunów rodzinnych seniorów było czterokrotnie mniej osób z wykształceniem wyższym. Dwukrotnie zaś więcej mieszkańców wsi, w tych samych okolicznościach, ukończyło wyłącznie szkołę podstawową. Natomiast zarówno na wsi, jak i miastach najwyższy udział stanowili opiekunowie ze średnim wykształceniem (tab. 2).

\footnotetext{
8 Dotąd w badaniach poziomu biedy tak na wsi, jak i mieście nie uwzględniano czynnika podjęcia się przez członka rodziny roli nieformalnego opiekuna seniora.

9 Średnia długość trwania życia mężczyzn w miastach wynosi 73,1 lat (Rocznik Statystyczny...2013, s. 213).

10 Dane opracowano na podstawie badań ankietowych ogółem 1000 respondentów przeprowadzonych w rejonie Polesia, Małopolski i Wielkopolski w ramach grantu EURO-FAMCARE (Czekanowski 2006, s. 87).
} 
Tabela 1. Wiek nieformalnych opiekunów rodzinnych seniorów w miastach i na wsi

\begin{tabular}{|l|c|c|c|}
\hline \multirow{2}{*}{ Grupa wiekowa } & \multicolumn{2}{|c|}{ Miejsce zamieszkania } & \multirow{2}{*}{$\begin{array}{c}\text { Różnica punktów procentowych } \\
\text { między danymi dla wsi i miasta* }\end{array}$} \\
\cline { 2 - 3 } & miasto (\%) & wieś (\%) & 5,6 \\
\hline $18-33$ & 10,6 & 16,2 & 14,6 \\
$34-49$ & 30,1 & 44,7 & $-8,1$ \\
$50-64$ & 34,9 & 26,8 & $-12,1$ \\
$65+$ & 24,4 & 12,3 & 0,0 \\
\hline Razem & 100,0 & 100,0 & 0 \\
\hline
\end{tabular}

*uzupełnienie W. Musialik

Źródło: P. Czekanowski (2006, s. 87).

Tabela 2. Poziom edukacji rodzinnych opiekunów seniorów w miastach i na wsi

\begin{tabular}{|l|c|c|c|}
\hline \multirow{2}{*}{\multicolumn{1}{|c|}{ Poziom wykształcenia }} & \multicolumn{2}{|c|}{ Miejsce zamieszkania } & \multirow{2}{*}{$\begin{array}{c}\text { Różnica punktów procentowych } \\
\text { między danymi dla wsi i miasta* }\end{array}$} \\
\cline { 2 - 3 } & miasto (\%) & wieś (\%) & 15,3 \\
\hline Podstawowy & 11,5 & 26,8 & 1,4 \\
Średni & 67,2 & 68,6 & $-16,7$ \\
Wyższy & 21,3 & 4,6 & 0,0 \\
\hline Razem & 100,0 & 100,0 & 0 \\
\hline
\end{tabular}

*uzupełnienie W. Musialik

Źródło: P. Czekanowski (2006, s. 89).

Wśród respondentów uczestniczących w badaniach EURO-FAMCARE, z których pochodzą przytaczane dane, w sektorze publicznym pracowało $26 \%$ wiejskich opiekunów rodzinnych seniorów. Wielkość ta była mniejsza o 11,3 p.p. w stosunku do tej grupy osób mieszkających w miastach. Na obszarach wiejskich było też o 21,5 p.p. mniej osób pracujących w sektorze prywatnym, pełniących jednocześnie rolę opiekuna seniora w stosunku do mieszkańców miast zatrudnionych w tym samym sektorze i zajmujących się także starszą osobie w rodzinie. Natomiast przeszło pięciokrotnie więcej było ich, tj. osób mieszkających na wsi i zajmujących się w rodzinach seniorami, wśród samozatrudniających się w stosunku do osób występujących w tych rolach, a mieszkających w miastach (tab. 3).

Tabela 3. Specyfika sektorów zatrudnienia pracujących rodzinnych opiekunów seniorów. Porównanie sytuacji na wsi i w miastach

\begin{tabular}{|l|c|c|c|}
\hline \multirow{2}{*}{$\begin{array}{c}\text { Sektor gospodarki zatrudnienia } \\
\text { lub statusu niepracującego } \\
\text { opiekuna }\end{array}$} & \multicolumn{2}{|c|}{ Miejsce zamieszkania } & \multirow{2}{*}{$\begin{array}{c}\text { Różnica punktów procentowych } \\
\text { między danymi dla wsi i miasta* }\end{array}$} \\
\cline { 2 - 3 } & miasto (\%) & wieś (\%) & $-11,3$ \\
\hline Publiczny & 37,3 & 26,0 & $-21,5$ \\
Prywatny & 53,6 & 32,1 & 32,8 \\
Samozatrudnienie & 7,6 & 40,4 & 0,0 \\
Inny typ pracy & 1,5 & 1,5 & 0,0 \\
\hline Razem & 100,0 & 100,0 & \\
\hline
\end{tabular}

*uzupełnienie W. Musialik

Źródło: P. Czekanowski (2006, s. 90). 
W grupie osób niepracujących zawodowo i zajmujących się seniorami w rodzinach na wsi było mniej emerytów (o 27,3 p.p.) i studentów (o 3,4 p.p.) w stosunku do osób mieszkających w miastach. Natomiast więcej na terenach wiejskich występowało w tej roli gospodyń domowych (o 4,9 p.p.) oraz bezrobotnych i poszukujących pracy (o 0,9 p.p.). Zdecydowanie też na obszarach wiejskich przeważała liczba osób przebywających na długoterminowym zwolnieniu lekarskim, ale zamierzających wrócić do pracy. Przeszło trzykrotnie wyższy był ich udział wśród ludności wiejskiej w porównaniu ze skalą występowania tej kategorii osób w miastach (tab. 4).

Tabela 4. Specyfika statusu niepracujących zarobkowo rodzinnych opiekunów seniorów. Porównanie sytuacji na wsi i w miastach

\begin{tabular}{|l|c|c|c|}
\hline \multirow{2}{*}{$\begin{array}{c}\text { Sektor gospodarki zatrudnienia } \\
\text { lub statusu niepracującego } \\
\text { opiekuna }\end{array}$} & \multicolumn{2}{|c|}{ Miejsce zamieszkania } & \multirow{2}{*}{$\begin{array}{c}\text { Różnica punktów procentowych } \\
\text { między danymi dla wsi i miasta* }\end{array}$} \\
\cline { 2 - 3 } Emeryt & miasto (\%) & wieś (\%) & $-27,3$ \\
Gospodyni domowa & 71,6 & 47,9 & 4,9 \\
Bezrobotny i szukający pracy & 12,6 & 17,5 & 0,9 \\
Przebywający na L-4 & 0,0 & 0,9 & 21,3 \\
Student & 9,0 & 30,3 & $-3,4$ \\
\hline Razem & 6,8 & 3,4 & 0,0 \\
\hline
\end{tabular}

*uzupełnienie W. Musialik

Źródło: P. Czekanowski (2006, s. 90).

Na obszarach wiejskich o 10 p.p. częściej roli opiekuna seniora pozostającego w rodzinie podejmowały się osoby pozostające w związkach małżeńskich bądź partnerskich. Wśród opiekunów seniorów na terenach rolniczych mniej było „singli” (o 4,6 p.p.) lub osób rozwiedzionych bądź pozostających w separacji (o 5,4 p.p.) (tab. 5).

Tabela 5. Stan cywilny opiekunów seniorów w rodzinie. Porównanie sytuacji we wsi i w miastach.

\begin{tabular}{|l|c|c|c|}
\hline \multirow{2}{*}{\multicolumn{1}{|c|}{ Stan cywilny }} & \multicolumn{2}{|c|}{ Miejsce zamieszkania } & \multirow{2}{*}{$\begin{array}{c}\text { Różnica punktów procentowych } \\
\text { między danymi dla wsi i miasta* }\end{array}$} \\
\cline { 2 - 3 } & miasto (\%) & wieś (\%) & 10,1 \\
\hline Małżeństwo/ko habitacja & 69,1 & 79,2 & $-4,6$ \\
Wolny & 16,9 & 12,3 & $-0,3$ \\
Wdowiec/wdowa & 6,6 & 6,3 & $-5,4$ \\
Rozwiedziony/separacja & 7,4 & 2,2 & $\times$ \\
\hline Razem & 100,0 & 100,0 & $\times$ \\
\hline
\end{tabular}

*uzupełnienie W. Musialik

Źródło: P. Czekanowski (2006, s. 93).

Podobnie jak w mieście, na wsi funkcje opiekuńcze seniorów podejmowane były w większości przez kobiety (Czekanowski 2006, s. 87). Jednak selektywna ich migracja ze wsi do miast (Gorlach 2000) przyczynia się do niedoboru żon czy córek mogących pełnić role opiekuńcze wobec osób w schyłkowych latach życia. Zadania te przypadają wiec synom, a przy ich emigracji, sąsiadom. Rzadko rozważa się powierzenie bliskiej osoby pod opiekę instytucjonalną. „W mniejszych środowiskach zdarza się - zdaniem Anny 
Janowicz - że oddanie bliskiego do specjalistycznego ośrodka wywołuje stygmatyzację rodziny i posądzenie o bezduszność lub też brak wdzięczności ze strony dzieci i wnuków" (Janowicz 2008, s 162).

\section{Skala potrzeb mieszkańców wsi wobec syndromu opiekuna osób starszych}

Niezależnie od wieku, a także miejsca zamieszkania - wsi lub miasta - osoba pełniąca opiekę nad seniorem doświadcza nie tylko strat dochodów pieniężnych, ale narażona jest na zdrowotne następstwa podjętej formy aktywności. W latach 90. XX w. zaczęto obserwować występowanie szeregu dolegliwości u nieformalnych opiekunów przez dłuższy czas podejmujących przyjęte zadanie (Smrokowska-Reichmann 2013). Przypadłości te określono syndromem (zespołem) opiekuna osób starszych CSS (Caregiver Stress Syndrome) czyli zespół fizycznego, emocjonalnego i psychicznego zmęczenia; poczucia bezradności i beznadziei, a także braku zainteresowania i entuzjazmu do pracy i życia (Lee i in. 2001, s. 114). Do fizycznych objawów takiego zespołu zaliczono dolegliwości psychosomatyczne i psychospołeczne. Należały do nich odczucia bólowe, zmęczenie, problemy ze snem, apetytem, uczucie pustki, osamotnienie izolacji czy też depresja. Jak stwierdziła B. Łukowska psycholog kliniczny z Zakładu Pielęgnacyjno-Opiekuńczy im. ks. Jerzego Popiełuszki w Toruniu: „Ciężar obowiązków, jakie musi udźwignąć opiekun prędzej czy później doprowadzi do określonych skutków psychofizycznych. [...] W pewnym sensie staje się [opiekun - W. M.] »więźniem « sytuacji związanej z chorobą podopiecznego. Jest zmuszony podporządkować swoje całe życie nowej roli" (Łukowska 2013).

Obowiązki nieformalnych opiekunów podejmują osoby w większości nieposiadające odpowiedniej praktycznej wiedzy w zakresie potrzeb zdrowotnych czy społecznych osób starszych. Niski poziom wykształcenia przeważającej części opiekunów mieszkających na wsi (Czekanowski 2006, s. 89) rzutuje na brak ich umiejętności samodzielnego pozyskiwania wiedzy czy też odczuwanie potrzeby jej poszerzania w zakresie przyjętych obowiązków opiekuńczych. Brak takich nawyków może doprowadzić do tragedii. Np. w 2008 r. we wsi Łęki w województwie małopolskim dwóch nieżonatych synów przyczyniło się do śmierci przez zagłodzenie 80-letniej matki (Synowie... 2009), w 2014 r. podobny wypadek miał miejsce w Bochni (Bochnia: Zostawiła ojca... 2014). Można stwierdzić, że w tym przypadku zawiódł system wsparcia ze strony pomocy społecznej skierowany do opiekunów, zabrakło koniecznej wiedzy. Wynika to m.in. z ograniczonego dostępu do specjalistów z zakresu gerontologii. W Polsce w 2005 r. na 10000 mieszkańców przypadało 0,3 lekarza geriatry (Szczerbińska i Pietryka 2008, s. 65). Obliczenia te prowadzono, nie różnicując dostępności tego rodzaju specjalisty w miastach i na wsi. Jednak liczba placówek zdrowotnych na wsi uświadamia dysproporcję w dostępie do geriatry nieformalnych opiekunów rodzinnych ze wsi w stosunku do opiekunów w miastach.

Do większej dociekliwości w zadawaniu pytań zniechęca też postawa rozmówców wobec nieformalnych opiekunów rodzinnych. Zgodnie z ustaleniami K. Warchoł-Biedermann troszczący się o seniorów w rodzinie, kontaktując się z osobami zawodowo zajmującymi się opieką społeczną lub środowiskową, często nie uzyskują od nich pomocy. Zauważono, że wielokrotnie spotykały się one wprost z odmową jej udzielenia, a zgłaszane przez nie problemy były bagatelizowane (Warchoł-Biedermann 2010, s. 108-109). 
Podobne reakcje otoczenia instytucjonalnego sprzyjają wycofaniu się opiekunów seniorów z prób szukania wsparcia w spełnianiu podjętej roli w rodzinie. Wyczerpani obciążeniami płynącymi z przyjętego zadania nie podejmują kolejnego wysiłku na rzecz zwrócenia uwagi na potrzeby im towarzyszące. Przyjmując taką postawę, stają się „niewidzialną” grupą osób wykluczonych w lokalnych społecznościach. Próbą wyjścia naprzeciw potrzebom owych opiekunów w środowiskach pozamiejskich byłoby tworzenie wiejskich domów dziennego pobytu. Perspektywę taką wyznaczyła w lutym 2015 r. premier Ewa Kopacz, ogłaszając plan stworzenia do końca roku ok. 100 domów dziennego pobytu seniora w ramach programu Senior-WIGOR. Program miał trwać do roku 2020 i zakładał założenie podobnych placówek w każdej gminie. Miał stanowić uzupełnienie działań realizowanych w ramach Rządowego Programu na rzecz Aktywności Społecznej Osób Starszych na lata 2014-2020 (100 razy wigor... 2015). Wdrożenie tego projektu pośrednio stwarzałoby możliwość odciążenia przynajmniej części opiekunów rodzinnych, także z terenów wiejskich, od troski o podopiecznych w czasie ich pobytu w takich placówkach. Pomoc uzyskaliby pośrednio w zakresie działań na rzecz usprawnienia seniora i przedłużenia okresu, w którym nie byłby zależny od pomocy innej osoby. Wydaje się, że w oparciu o funkcjonowanie owych domów istnieje szansa na rozwój systemu edukacji i wsparcia psychologicznego nieformalnych opiekunów seniorów w przyjętych obowiązkach. Pozycję tej grupy zasadniczo zmieniłoby uznanie ich za interesariuszy działań ekonomicznych (Musialik 2015, s.73-80). Jednak w tym przypadku istotną barierą korzystania z takiej pomocy pozostają kwestie finansowe.

\section{Rekomendacje}

W polityce okołosenioralnej należy upodmiotowić pozycję ich opiekunów w rodzinach. Zmiana wizerunku społecznego powinna objąć tak mieszkańców wsi, jak i miast. Działania powinny mieć wymiar przedsięwzięć długookresowych, wymagających wysiłków edukacyjnych, a także rozwiązań systemowych, takich jak:

- Budowa instrumentów finansowych wspierających zmiany społeczne, np. do zadań finansowanych z dotacji budżetowych terenów wiejskich dodanie współfinansowania społecznych funduszy finansowych. Ich rola polegałaby na połączeniu rozwiązania kosztochłonnego, takiego jak Wiejskich Dziennych Domów Pobytu Seniorów wraz z usługą dowozu użytkowników, z funduszem kapitałowym lub dochodowym przedsięwzięciem.

- Przeznaczenie części podatku od przychodów kapitałowych (podatek Belki) na rzecz funduszu płac dla nieformalnych opiekunów rodzinnych. Uzależnienie wynagrodzenia za tę funkcję od czasu poświęconego na opiekę, niezależnie od tego, czy jest zatrudniona, czy też nie, czy mieszka lub nie z podopiecznym.

- Rozwój sieci zewnętrznego wsparcia dla osób pełniących funkcje nieformalnych opiekunów rodzinnych w oparciu o system grantów wspomagających społeczną innowacyjność w poszukiwaniu rozwiązań ułatwiających funkcjonowanie nieformalnych opiekunów.

- Zrównoważenie rozwiązania ustawowego wsparcia materialnego na rzecz opiekunów rodzinnym dzieci i seniorów przez:

- wprowadzenie podobnych norm prawnych, wspomagających nieformalnych opiekunów seniorów, do wsparcia rodziców dzieci, 
- rozszerzenie prawa do wolnych dni w pracy na rzecz opieki nad seniorami do liczby porównywalnej z „urlopami na dziecko”,

- wprowadzenie płatnych urlopów opiekuńczych dla opiekunów osób obłożnie chorych, np. w ostatniej fazie chorób nowotworowych itp.

- czas opieki nad seniorem zaliczyć do stażu pracy.

- Upowszechnienie na wsi form szkoleniowych z zakresu trudności i potrzeb osób pełniących opiekę nad niesamodzielnym seniorem finansowanych z mechanizmu Europejskiego Obszaru Gospodarczego.

- Zwiększenie dostępności profilaktyki zapobiegającej zespołowi CSS (stresu opiekuńczego).

- Przeprowadzenie monitoringu skali występowania problemu w poszczególnych gminach i dostosowanie wsparcie zmierzającego do pobudzenia aktywności lokalnych społeczności.

\section{Literatura}

100 razy wigor. Powstanq domy dziennego pobytu seniora - obiecuje minister_www.samorzad.pap. pl/depesze/wiadomosci_centralne/148894/100__25.06.2015.

Bednarska M., 1976, Etnografia Polski. Przemiany kultury ludowej, t. 1, Ossolinem, Wrocław.

Błędowski P., Szatur-Jaworska B., Szweda-Lewandowska Z., 2012, Raport na temat sytuacji osób starszych w Polsce, Instytut Pracy i Spraw Socjalnych, Warszawa.

Bochnia: Zostawiła ojca i wyjechała na wakacje. Ten zmart, www.wiadomosci.onet.pl/krakow/ bochnia-zostawila-ojca-i-wyjechala-na-wakacje-ten-zmarl/s1edv_2.04.14

Brzostek A., 2015, Od 2015 roku zmiany w specjalnym zasitku opiekuńczym, www.praca.gazetaprawna.pl/artykuly/842192,specjalny-zasilek-opiekunczy-2015-zmiana-kryetum-dochodowego. html_27.03.15

Czekanowski P., 2006, Family carers of elderly people, [w:] B. Bień (red.), Family caregiving of the elderly in Poland, Wydawnictwo Uniwersyteckie, Białystok.

Dzienio K. Lach M., 1983, Polityka ludnościowa europejskich krajów socjalistycznych, Państwowe Wydawnictwo Ekonomiczne, Warszawa.

Eile S., 1973, Światopoglqad powieści, Zakład Narodowy imienia Ossolińskich, Wrocław.

Fauve-Chamoux A., 1991, Starość i starzenie się w rodach pirenejskich w XVIII-XIX w. Przeszłość demograficzna Polski, 18, s. 225-244.

Godlewska J., 1984, Urlop i zasiłek macierzyński, Instytut Wydawniczy Związków Zawodowych, Warszawa.

Gorlach K. (red.), 2000, Raport o Rozwoju Społecznym 2000, https://books.google.pl/books? id=iTDFSECe0e8C\&printsec=frontcover\&dq=inauthor:\%22UNDP+Polska\%22\&hl=pl\&sa=X\&ei=ceP BVMmiKcPOaMXZgqgL\&ved=0CDMQ6AEwBA\#v=onepage\&q\&f=false_22.01.15

Graniewska D., Balcerzak-Paradowska B., Staszewska D., 1991, Okresowa dezaktywizacja kobiet wychowujacych dzieci jako element polityki rodzinnej, Instytut Pracy i Spraw Socjalnych, Warszawa.

Grzelak Z., 1981, Inteligencja w społeczności wiejskiej, Ludowa Spółdzielnia Wydawnicza, Warszawa.

Inglot S. (red.), 1980, Historia chłopów polskich. Okres II Rzeczypospolitej i okupacji hitlerowskiej, Muzeum Historii Ruchu Ludowego, Warszawa. 
Janowicz A., 2014, Rola opiekunów nieformalnych w opiece ukresu życia. Przyczynek do badań w ramach projektu European Palliative Care Academy (EUPCA), Pielęgniarstwo i Zdrowie Publiczne, 4, 2, s. 161-167.

Jurek Ł., 2007, Sektory opieki długoterminowej - analiza kosztów. Long term-care sectors - costs analysis, Gerontologia Polska, 15, 4, s. 111-115.

Karczewska B., Bień B., Ołdak E., Jamiołkowski J., 2012, Opiekunowie rodzinni osób starszych z otępieniem lub zaburzeniami poznawczymi w Polsce - czynniki ryzyka obciqzienia opiekq. Family caregivers of older people with dementia or cognitive disorders in Poland - risk factors of care burden, Gerontologia Polska, 20, 2, s. 59-67.

Kawczyńska-Butrym Z., 2008, Wyzwania rodziny: zdrowie, choroba, niepełnosprawność, starość, Wydawnictwo Makmed, Lublin.

Kołaczek B., 1990, Rola pośrednictwa pracy w aktywizacji zawodowej kobiet na urlopach wychowawczych, Instytut Pracy i Spraw Socjalnych, Warszawa.

Lee H., Song R., Shin H., 2007, Caregiver burnout, [w:] E.L. Siegler, E. Capezuti, M. Mezey (red.), The Encyclopedia of Elder Care. The Comprehensive Resource on Geriatric, New York, s. 113-121.

Łoch E., Kruk S., Flis-Czerniak E., 2006, Dojrzewanie do pełni życia. Starość w polskiej literaturze, Wydawnictwo Uniwersytetu Marii Curie-Skłodowskiej, Lublin.

Łukowska B., 2013, Zespół stresu opiekuna, MEDI 1/2013_http://dps.pl/domy/index.php? rob=radar\&dzial=10\&art=1617_24.03.15

Mazur G. (red.), 2009, Urlopy macierzyńskie - z uwzględnieniem zmian przepisów wchodzqcych w życie w latach 2009-2014, Wydawnictwo Wiedza i Praktyka, Warszawa.

Michalkiewicz S. (red.), 1985, Historia Ślq̨ska, Zakład Narodowy imienia Ossolińskich, Wrocław.

Musialik W., 2015, Upodmiotowienie nieformalnych opiekunów rodzinnych w perspektywie społeczeństwa biznesu, [w:] L. Karczewski, H. Kretek (red.), Społeczne i kulturowe determinanty biznesu, gospodarki i zarzq̨dzania, Seria: Studia i Materiały, 421, Wydział Ekonomii i Zarządzania Politechniki Opolskiej, Opole, s. 73-80.

Nysa zapowiada wprowadzenie bonu opiekuńczo-wychowawczego, www.wiadomosci.onet.pl/opole/nysa-zapowiada-wprowadzenie-bonu-opiekunczo-wychowawczego/2z86eh_21.03.2015.

O cenach usług opiekunek, 2012, www.cennik-uslug.pl/aktualnosci/190-o-cenach-uslug-opiekunek_31.03.2015.

Omyła-Rudzka M., 2012, Komunikat z badań, BS/83/2012, Społeczna solidarność z osobami w starszym wieku, CBOS, Warszawa.

Racław M., 2012, Opiekunowie nieformalni. Krótkookresowa funkcjonalność nieopłacanej pracy [w:] J. Hryniewicz (red.), O sytuacji ludzi starych, Warszawa, s. 71-82.

Sadowska-Snarska C., Tchon L., 2008, Godzenie pracy z rodzinq w kontekście aktywizacji zawodowej kobiet, Wydawnictwo Wyższej Szkoły Ekonomicznej, Białystok.

Simonides D., 1989, Folklor Górnego Ślq̨ska, Wydawnictwo „Śląsk”, Katowice.

Skorupka T., 1974, Kto przy Obrze, temu dobrze. Wspomnienia rolnika wielkopolskiego 1862-1935, Wydawnictwo Poznańskie, Poznań.

Smrokowska-Reichmann A., 2013, „Toksyczny senior” w perspektywie praktyki opiekuńczej, MEDI 1/2013_www. dps.pl/domy/index.php? rob=recenzje\&id=2\&recenzje=93_19.11.2014.

Synowie zagłodzili 80-letniq matkę, 2009, www.wiadomosci.wp.pl/kat, 83914,wid, 10777214_prasa.html_31.03.2015

Szczerbińska K., Pietryka A., 2008, Rozwój geriatrii w krajach europejskich - historia i zasoby, cz. 1, Gerontologia Polska 16, 2, s. 61-72. 
Świętek J., 1896 [?], Zwyczaje i pojęcia prawne ludu nadrabskiego, Materyały antropologiczno-archeologiczne i etnograficzne, Akademia Umiejętności, Kraków, s. 266-284, 298-362.

Titkow A., Duch-Krzystoszek D., Budrowska B., 2004, Nieodpłatna praca kobiet: mity, realia, perspektywy, Wydawnictwo IFiS PAN, Warszawa.

Warchoł-Biedermann K., 2010, Wybrane czynniki wpływajace na poczucie straty u opiekunów rodzinnych osób z chorobq Alzheimera, Promotor: prof. dr hab. M. D. Głowacka, Zakład Psychologii Klinicznej Katedry Nauk o Zdrowiu, UM w Poznaniu, Poznań (Wielkopolska Biblioteka Cyfrowa; dostęp 6.06.2013).

Zasitek pielęgnacyjny a dodatek pielęgnacyjny_www.infor.pl/prawo/pomoc-spoleczna/emeryt/ 285185,html_25.03.2015.

\section{Summary}

The aim of this research was to present selected problems of informal caregivers, who take care of elderly family members. The economic aspect of caregivers' unpaid labor was estimated. The study considered structure of seniors' care assistants in terms of age, education level, marital status and employment sector of workers and activity type of the unemployed. Data concerning rural areas was confronted with figures characterizing urban areas. Based on literature review in the field of gerontology, nursing and public health the author identified health and social risks related to the role of caregiver for people, who are "in the twilight" of their lives. It was found that theoretical knowledge concerning Caregiver Stress Syndrome (CSS) present in Polish scientific publications for the last five years does not reflect the actual needs of informal caregivers, who look after elderly family members. Public attention mainly focuses on seniors without recognizing the needs of caregivers. 